\title{
PELAKSANAAN PEMBELAJARAN MENULIS NASKAH DRAMA SISWA KELAS VIII SMP NEGERI 15 KOTA BENGKULU
}

\author{
'Dedi Arianto; ${ }^{2}$ Gumono; ${ }^{3}$ Suhartono \\ 1,2,3 Program Studi Pendidikan Bahasa Indonesia FKIP Universitas Bengkulu
}

Abstrak

\section{Korespondensi: dediarianto19april@gmail.com}

Tujuan penelitian ini untuk mendeskripsikan pelaksanaan proses pembelajaran menulis naskah drama siswa kelas VIII SMP Negeri 15 Kota Bengkulu. Metode yang digunakan dalam penelitian ini adalah metode deskriptif kualitatif. Subjek dalam penelitian ini adalah guru dan siswa yang sedang melaksanakan pembelajaran menulis naskah drama di kelas VIII SMP Negeri 15 Kota Bengkulu. Teknik pengumpulan data menggunakan observasi, wawancara dan dokumentasi. Uji keabsahan data yang digunakan adalah triangulasi sumber. Hasil penelitian menunjukkan bahwa pelaksanaan pembelajaran menulis naskah drama di kelas VIII dilaksanakan menggunakan pendekatan saintifik. Kegiatan pembelajaran dilaksanakan berdasarkan Rencana Pelaksanaan Pembelajaran yang telah dibuat oleh guru. Guru menjelaskan materi dan memberikan petunjuk mengerjakan tugas menulis naskah drama dengan metode ceramah, siswa mengerjakan tugas dan mengumpulkan tugas berupa naskah drama dan kemudian guru menilai naskah drama siswa berdasarkan kriteria penilaian yang terdapat di dalam Rencana Pelaksanaan Pembelajaran.

Kata Kunci: pelaksanaan pembelajaran, menulis, dan naskah drama

\section{Abstract}

The aim of this study was to describe the implementation of drama script writing's lesson for second grade students of SMP Negeri 15 Kota Bengkulu. The method used in this study was a qualitative descriptive method. The subject in this study where teacher who was carrying out the implementation of teaching and learning and students who were studying drama script writing's lesson in the second-grade students of SMP Negeri 15 Kota Bengkulu. Moreover, techniques of collecting data used were observation, interview and documentation. The validity test of the data used in this study was source triangulation. The results of the study showed that the implementation of drama script writing's lesson in second grade students used a scientific approach and was carried out based on lesson plan that has been made by the teacher. The teacher gave instructions on doing drama script writing task, student finished the task, collected the task and then the teacher assessed the drama script written by students based on the assessment criteria containing the lesson plan.

Keywords: the implementation of learning, writing, and drama scripts. 


\section{PENDAHULUAN}

Pembelajaran merupakan suatu proses pendidikan yang memberikan kesempatan pada seseorang untuk mengembangkan potensi diri agar potensi atau kemampuan yang dimiliki dapat dikembangkan dengan maksimal. Melalui pembelajaran seseorang akan memperoleh pengetahuan yang luas serta keterampilan yang kompleks. Dalam konteks pembelajaran, bahasa memiliki peran yang penting oleh karena dengan bahasa siswa dapat mengungkapkan yang dialami dan dirasakannya baik secara tulis maupun secara lisan. Dengan demikian, mereka dapat menunjukkan ekspresi mengenai yang dirasakan karena hakikat bahasa sendiri yaitu alat yang berfungsi untuk berinteraksi atau alat untuk berkomunikasi dalam arti alat untuk menyampaikan ide, pikiran, gagasan, konsep, atau juga perasaan (Chaer, 2004:14). Kemampuan menulis merupakan salah satu bentuk keterampilan berbahasa yang harus dikuasai oleh siswa. Menulis adalah kegiatan menyampaikan gagasan atau ide dalam bentuk tulisan. Dilihat dari pengertian umum, menulis adalah aktivitas mengemukakan gagasan melalui bahasa dengan tujuan yang bermacam-macam. Kegiatan menulis merupakan kemampuan produktif karena dengan menulis berarti kita menghasilkan suatu karya. Menulis juga merupakan kegiatan ekspresif karena dengan tulisan kita dapat mengekspresikan yang sedang kita alami. Menurut Alwasilah (2005:111) jika ditinjau berdasarkan tujuannya ada beberapa bentuk tulisan, yaitu;

a. Penulisan yang bertujuan memberikan informasi, penjelasan, keterangan, atau pemahaman termasuk golongan pemaparan, hasilnya dapat disebut pemaparan atau eksposisi.

b. Penulisan yang bertujuan meyakinkan orang, membuktikan pendapat atau pendirian pribadi, atau membujuk pihak lain agar pendapat pribadi diterima, termasuk golongan pembahasan, hasilnya dapat disebut bahasan, persuasi, atau argumentasi.

c. c. Penulisan yang tujuannya untuk bercerita, baik berdasarkan pengamatan maupun berdasarkan perekaan, dan yang tujuannya lebih banyak mengimbau, tergolong kategori pengisahan, hasilnya dapat disebut kisahan atau narasi.

d. Penulisan yang menggambarkan bentuk objek pengamatan, rupanya, sifatnya, rasanya, atau coraknya termasuk golongan pemerian, hasilnya dapat disebut pemerian atau deskripsi.

Pendekatan berbasis teks dalam Kurikulum 2013 (K-13) disusun untuk mengembangkan pengetahuan (KI-3) dan keterampilan (KI-4) siswa dalam memahami dan menyusun berbagai jenis teks sesuai dengan jenjang. Dalam Kurikulum 2013, terdapat beberapa kompetensi menulis sastra yang harus dikuasai oleh siswa, salah satunya, yaitu siswa diharapkan mampu menulis naskah drama secara individu maupun secara kelompok. Hal ini tertuang dalam Kurikulum 2013 (K13) tepatnya pada KD 4.16 "Menyajikan drama dalam bentuk pentas atau naskah."

Drama berasal dari bahasa Yunani 'draomai' yang berarti berbuat, bereaksi, bertindak, dan sebagainya; dan "drama" berarti berbuat, atau bertindak (Harymawan, 1993:1). Naskah Drama adalah karangan yang menggambarkan kehidupan dan watak manusia dalam bertingkah laku yang dipentaskan dalam beberapa babak. Ada banyak unsur yang menjadi pembangun dalam sebuah naskah drama. Menurut Waluyo (2001:8) unsur-unsur pembangun dalam sebuah naskah drama yaitu : plot, tokoh, penokohan dan perwatakan, dialog, setting, tema, amanat dan petunjuk teknis. 
SMP Negeri 15 Kota Bengkulu merupakan salah satu lembaga sekolah jenjang Pendidikan Menengah Pertama berstatus negeri yang terletak di Jalan Cempaka X, Kebun Beler, Kecamatan Ratu Agung Kota Bengkulu yang telah menerapkan Kurikulum 2013 (K-13). Topik menulis naskah drama tergolong cukup sulit karena siswa merasa bosan dan beranggapan bahwa menulis naskah drama merupakan pelajaran yang sulit dibandingkan dengan karya sastra yang lain sehingga pembinaan keterampilan menulis naskah drama harus mendapatkan perhatian yang sungguh-sungguh, baik dari segi siswa maupun dari segi guru sebagai tenaga pendidik yang akan membimbing kegiatan belajar. Maka dari itu, peneliti merumuskan masalah penelitian yaitu Bagaimanakah pelaksanaan pembelajaran menulis naskah drama siswa kelas VIII SMP Negeri 15 Kota Bengkulu? Penelitian ini bertujuan untuk mengetahui pelaksanaan proses pembelajaran menulis naskah drama siswa kelas VIII SMP Negeri 15 Kota Bengkulu. Penelitian diharapkan dapat memberi pandangan baru serta menjadi bahan pengembangan dalam kegiatan pembelajaran menulis naskah drama, selanjutnya bagi guru hasil penelitian ini dapat dijadikan bahan pertimbangan dalam meningkatkan keterampilan pembelajaran menulis naskah drama.

Kegiatan pembelajaran menulis naskah drama sama halnya dengan kegiatan pembelajaran menulis teks lainnya yang meliputi kegiatan pendahuluan, kegiatan inti pembelajaran dan kegiatan penutup. Dalam Peraturan Menteri Pendidikan dan Kebudayaan (Permendikbud) Nomor 22 Tahun 2016 dijelaskan bahwa pelaksanaan pembelajaran merupakan implementasi dari RPP yang meliputi kegiatan pendahuluan, kegiatan inti dan kegiatan penutup. Adapun penjelasannya adalah seperti berikut ini:

a. Kegiatan Pendahuluan

Pendahuluan adalah kegiatan awal dalam suatu pertemuan pembelajaran yang bertujuan untuk memotivasi dan memfokuskan peserta didik supaya dapat berpartisipasi aktif dalam pelaksanaan pembelajaran.

b. Kegiatan Inti Pembelajaran

Kegiatan inti merupakan proses pembelajaran untuk mencapai kompetensi dasar (KD). Kegiatan inti menggunakan model pembelajaran, media pembelajaran, dan sumber belajar yang disesuaikan dengan karakteristik siswa dan mata pelajaran.

c. Kegiatan Penutup

Menurut Mulyasa (2007:186) kegiatan penutup mencakup kegiatan menarik kesimpulan/meninjau kembali mengenai materi yang telah dipelajari, mengadakan evaluasi/penilaian, dan memberikan tindakan lanjut terhadap materi yang telah dipelajari.

\section{METODE}

Metode yang digunakan dalam penelitian ini, yaitu metode kualitatif deskriptif. Pendekatan ini digunakan untuk mendapatkan gambaran suatu keadaan pada saat penelitian berlangsung. Penelitian ini dilaksanakan di SMP Negeri 15 Kota Bengkulu yang beralamatkan di Jalan Cempaka X, Kebun Beler, Kecamatan Ratu Agung Kota Bengkulu. Data dalam penelitian ini yaitu kegiatan guru saat proses pembelajaran menulis naskah drama di kelas. Sumber datanya yaitu guru Bahasa Indonesia dan siswa kelas VIII SMP Negeri 15 Kota Bengkulu yang sedang melaksanakan kegiatan pembelajaran.

Teknik pengumpulan data yang digunakan dalam penelitian ini secara garis besar adalah observasi atau pengamatan partisipatif (langsung), dokumentasi, dan wawancara. 
Melalui observasi peneliti mengamati aktivitas guru dan aktivitas siswa selama proses pembelajaran menulis teks/naskah drama berlangsung. Kegiatan observasi dilakukan secara terus-menerus dan berkesinambungan hingga mendapatkan data yang cukup. Wawancara digunakan sebagai alat rechecking atau pembuktian terhadap informasi atau keterangan yang diperoleh sebelumnya. digunakan sebagai langkah untuk menggali informasi lebih lanjut terkait pembelajaran menulis naskah drama kelas VIII di SMP Negeri 15 Kota Bengkulu. Instrumen utama dalam pengumpulan data yaitu peneliti sendiri yang dilengkapi dengan lembar observasi, pedoman wawancara guru dan dokumentasi melalui satu unit telepon genggam.

Teknik analisis data dalam penelitian ini dilakukan dengan langkah-langkah: (1) Membaca data lapangan yang didapat selama pengambilan data sekaligus memilih antara mana yang penting dan mana yang tidak penting. (2) Data yang diperoleh dari lapangan dibuat ringkasan untuk mengarahkan kepada hal yang berkaitan dengan penelitian. (3) Mengelompokkan dan menabulasi data berdasarkan langkah pembelajaran (Kegiatan Pendahuluan, Kegiatan Inti Pembelajaran, dan Kegiatan Penutup). (4) Memberikan kode data berupa penomoran percakapan siswa dan guru selama pelaksanaan pembelajaran berlangsung. (5) Menginterpretasi data yang telah dikelompokkan berdasarkan langkahlangkah pembelajaran sehingga menjadi presentasi naratif yang berisi uraian mengenai pelaksanaan pembelajaran menulis naskah drama kelas VIII SMP Negeri 15 Kota Bengkulu. (6) Menarik kesimpulan terhadap data yang telah dianalisis. Uji keabsahan data dalam penelitian ini dilakukan dengan triangulasi sumber menggunakan Rencana Pelaksanaan Pembelajaran (RPP) teks drama dan guru mata pelajaran Bahasa Indonesia..

\section{HASIL DAN PEMBAHASAN}

Pembelajaran menulis naskah drama pada kelas VIII di SMP Negeri 15 Kota Bengkulu merupakan bagian dari pembelajaran Bahasa Indonesia yang dilaksanakan selama 8 Jam Pelajaran (4 x pertemuan) sesuai dengan jadwal yang telah ditentukan oleh pihak sekolah. Adapun yang menjadi titik fokus dalam penelitian ini adalah kegiatan pembelajaran menulis naskah drama, meliputi kegiatan pendahuluan, kegiatan inti dan kegiatan penutup dengan berpedoman pada Rencana Pelaksanaan Pembelajaran (RPP) guru yang diuraikan sebagai berikut:

1. Kegiatan Pendahuluan

Berdasarkan hasil penelitian pada keempat pertemuan, guru memulai pembelajaran berdasarkan komponen-komponen pendahuluan yang meliputi: Menyiapkan siswa secara fisik dan psikis, pengecekan kehadiran siswa, apersepsi dan motivasi, serta penyampaian tujuan pembelajaran. Ketika guru masuk ke dalam kelas, siswa memberikan salam serentak dan membaca do'a secara bersama-sama yang dipimpin oleh ketua kelas, hal ini merupakan kegiatan rutin siswa khususnya ketika guru masuk pada jam pelajaran pertama. Hal ini merupakan kegiatan yang baik untuk dilaksanakan karena kegiatan ini berhubungan dengan penerapan kompetensi sikap spiritual sebagai perwujudan penguatan interaksi vertikal dengan Tuhan Yang Maha Esa.

Pada awal pembelajaran guru menyiapkan siswa secara fisik dan psikis untuk mengikuti proses pembelajaran. Kegiatan menyiapkan siswa secara fisik dan psikis ini perlu dilakukan pada saat memulai pembelajaran karena bertujuan untuk membuat siswa siap secara fisik maupun mental dalam menerima materi yang akan diajarkan. Seperti yang dijelaskan Aswan Zain (2010:1) kegiatan membuka pelajaran adalah 
kegiatan yang dilakukan oleh guru untuk menciptakan suasana pembelajaran yang memungkinkan siswa siap secara mental untuk mengikuti kegiatan pembelajaran. Kegiatan pendahuluan selanjutnya yaitu guru melakukan pengecekan kehadiran siswa. Berdasarkan hasil penelitian, dari kegiatan pengecekan kehadiran guru langsung memotivasi siswa agar tetap rajin ke sekolah. Dalam pembelajaran, guru dapat memberi motivasi dari berbagai aspek, misalnya dari aspek kerapian, aspek kebersihan, aspek prestasi dan aspek-aspek lainnya. Hendaknya kegiatan ini dilakukan pada setiap pertemuan supaya siswa semangat dalam mengikuti kegiatan belajar.

Kegiatan selanjutnya yaitu apersepsi yang diharapkan dapat membangun peran aktif siswa dalam kegiatan pembelajaran. Dari hasil pengamatan, pada setiap pertemuan guru melakukan apersepsi dengan memberikan sejumlah pertanyaan yang berhubungan dengan materi yang akan dipelajari pada hari itu.

Kegiatan pendahuluan selanjutnya yaitu menjelaskan tujuan pembelajaran atau kompetensi dasar yang akan dicapai. Pada keempat pertemuan di kelas, guru menyampaikan tujuan pembelajaran secara umum hanya pada saat pertemuan pertama sesuai dengan RPP yang digunakan oleh guru. Tujuan pembelajaran merupakan rumusan tentang perubahan perilaku apa yang diperoleh setelah proses belajar mengajar. Apabila tujuan belajar diketahui, peserta didik mempunyai motivasi untuk belajar. Agar tujuan mudah diketahui, maka tujuan harus dirumuskan secara khusus (Uno, 2006:7). Maka dari itu tujuan pembelajaran pada setiap pertemuan haruslah dikemukakan dengan jelas. Hendaknya tujuan pembelajaran juga disampaikan secara berkala pada setiap pertemuan agar siswa paham dengan apa yang akan mereka capai. Dengan adanya kegiatan pendahuluan, maka pembelajaran akan siap dimulai atau dilaksanakan berdasarkan kurikulum 2013 (Rusman, 2013:11).

2. Kegiatan Inti Pembelajaran

Kegiatan inti merupakan proses pembelajaran untuk mencapai Kompetensi Dasar (KD). Kegiatan inti berhubungan dengan proses pembelajaran yang terkait dengan penggunaan model pembelajaran, media pembelajaran, dan sumber belajar yang disesuaikan dengan karakteristik siswa, mata pelajaran dan RPP yang digunakan.

Dalam pelaksanaan pembelajaran, guru menerapkan pendekatan Saintifik sesuai dengan yang tertuang di dalam RPP yang digunakan. Seperti yang dikemukakan oleh Daryanto (2014:59) Pembelajaran dengan pendekatan saintifik ini memuat langkah-langkah yaitu (1) Mengamati, merupakan metode yang mengutamakan kebermaknaan proses pembelajaran. Adapun kegiatan yang dilakukan dalam proses mengamati adalah membaca, mendengar, menyimak, melihat. Kegiatan ini terlihat ketika setiap kelompok menerima naskah drama yang dibagikan oleh guru, setiap anggota kelompok diberikan instruksi untuk mengidentifikasi unsur-unsur pembangun naskah drama dari naskah yang diberikan. (2) Menanya, merupakan kegiatan pembelajaran yang dilakukan dengan cara mengajukan pertanyaan tentang informasi yang tidak dipahami dari apa yang diamati, merupakan kegiatan pembelajaran yang berupa eksperimen, membaca sumber lain selain buku teks, mengamati objek/kejadian/aktivitas dan wawancara dengan narasumber. Dalam hal ini, guru memberikan kesempatan kepada siswa untuk bertanya terhadap apa yang belum dipahami mengenai materi yang sedang dijelaskan. Guru membimbing siswa untuk mengajukan pertanyaan-pertanyaan mengenai topik pembahasan sehingga terjadilah interaksi tanya jawab antara siswa dan guru. (3) Mengumpulkan Informasi, 
kegiatan pembelajaran yang berupa pengolahan informasi yang sudah dikumpulkan. Berdasarkan hasil penelitian, kegiatan ini dilaksanakan ketika guru memberikan kesempatan kepada siswa untuk mengumpulkan informasi mengenai topik pembelajaran baik yang bersumber dari buku maupun dari internet. (4) Mengasosiasi atau menalar. Dalam pembelajaran pada K-13, siswa diharapkan lebih aktif sehingga diberikan kebebasan dalam mencari informasi dan mengemukakan pendapatnya sedangkan guru sebagai fasilitator berperan dalam mengarahkan pembelajaran. Berdasarkan pengamatan, hal ini masih belum berjalan secara maksimal karena siswa masih banyak yang tergolong pasif, hanya ada beberapa siswa yang terlihat aktif dalam mengikuti kegiatan pembelajaran. (5) Mengomunikasi atau menarik kesimpulan, merupakan kegiatan pembelajaran yang berupa menyampaikan hasil pengamatan, kesimpulan berdasarkan hasil analisis secara lisan, tertulis atau media lainnya. Pada pembelajaran menulis naskah drama ini, guru menerapkan mengomunikasi dengan memberikan kesempatan kepada siswa untuk melakukan presentasi mengenai unsur naskah drama secara berkelompok. Dari kegiatan mengomunikasi ini juga dapat dilihat kompetensi sikap sosial yang dimiliki oleh siswa karena pada sikap sosial ini siswa diharapkan mampu menciptakan suasana harmoni antara sesama siswa dan guru di kelas.

Dalam pelaksanaan pembelajaran, guru memberikan tugas secara bervariasi kepada siswa. Hal ini dilakukan sebagai salah satu strategi guru untuk menciptakan suasana kelas agar pembelajaran tidak membosankan. Berdasarkan penelitian, dalam kegiatan pembelajaran guru tidak menggunakan proyektor LCD dan media lainnya sebagai alat bantu untuk mempermudah pembelajaran. Pada saat menjelaskan materi, guru menggunakan metode ceramah sehingga siswa hanya mendengarkan yang dijelaskan oleh guru di depan kelas. Dalam K-13 guru diharuskan menggunakan media yang bervariasi dalam pembelajaran. Penggunaan media yang bervariasi juga harus sesuai dengan materi yang akan dipelajari.

3. Kegiatan Penutup

Dalam kegiatan penutup, guru bersama siswa baik secara individual maupun kelompok melakukan refleksi untuk mengevaluasi seluruh rangkaian pembelajaran dan hasil-hasil yang diperoleh untuk selanjutnya secara bersama-sama menemukan manfaat langsung maupun tidak langsung dari pelaksanaan pembelajaran yang telah berlangsung. Kegiatan penutup mencakup kegiatan menarik kesimpulan/meninjau kembali mengenai materi yang telah dipelajari, mengadakan penilaian, dan memberikan tindak lanjut terhadap materi yang telah dipelajari. Berdasarkan hasil penelitian setelah menulis naskah drama, guru secara langsung melakukan kegiatan refleksi terhadap siswa dengan menanyakan mengenai apa saja yang mereka dapatkan setelah mengikuti pembelajaran materi drama. Kegiatan evaluasi dan refleksi hendaknya dilakukan oleh guru secara berkala pada setiap akhir pertemuan supaya dapat memantau ketercapaian tujuan pembelajaran dan penguasaan materi oleh siswa dari setiap pertemuan.

Kegiatan penutup yang selanjutnya adalah menginformasikan rencana kegiatan pembelajaran pertemuan berikutnya. Hal ini dilakukan supaya siswa dapat mempersiapkan diri untuk belajar mengenai topik baru di rumah masing-masing 


\section{PENUTUP}

Berdasarkan hasil penelitian dan pembahasan, dapat disimpulkan bahwa proses pembelajaran menulis naskah drama pada mata pelajaran bahasa Indonesia di SMP Negeri 15 Kota Bengkulu dilaksanakan sesuai dengan langkah pembelajaran yaitu: (1) Kegiatan Pendahuluan yang mencakup penyiapan fisik dan psikis terhadap siswa yang dilaksanakan pada setiap pertemuan, Motivasi dan Apersepsi yang dilaksanakan hanya pada dua pertemuan, serta menjelaskan tujuan pembelajaran yang akan dicapai yang dijelaskan hanya pada pertemuan pertama. (2) Kegiatan Inti Pembelajaran yang mencakup penjelasan materi yang dilakukan dengan metode ceramah, pemberian tugas dengan cara yang bervariasi, dan penerapan pendekatan saintifik.

Berdasarkan penelitian, materi yang dijelaskan oleh guru selama proses pembelajaran sesuai dengan kurikulum 2013 pada KD dan tujuan pembelajaran dalam RPP yang terdiri dari hakikat naskah drama, unsur pembangun naskah drama, struktur naskah drama, kaidah kebahasaan naskah drama serta kegiatan mengonversi naskah drama dari sebuah cerita pendek dan hasilnya berupa teks drama siswa yang dikumpulkan untuk dikoreksi dan dinilai oleh guru. (3) Kegiatan Penutup yang meliputi refleksi yang hanya dilakukan pada pertemuan ke empat, menginformasikan rencana kegiatan pembelajaran pertemuan berikutnya hanya dilakukan pada pertemuan ketiga, serta menutup pembelajaran dengan salam yang dilakukan pada akhir pertemuan. Berdasarkan hasil penelitian dapat disimpulkan bahwa pelaksanaan pembelajaran menulis naskah drama pada siswa kelas VIII SMP Negeri 15 Kota Bengkulu berjalan lancar sesuai dengan tahap-tahap pembelajaran yang tertuang di dalam RPP buatan guru. Dalam proses pembelajaran, guru tidak menggunakan media serta metode pengajaran yang digunakan oleh guru yaitu metode ceramah.

Berdasarkan hasil penelitian dan pembahasan dalam penelitian ini, maka peneliti memberikan saran sebagai berikut: Bagi sekolah untuk menyediakan media agar pelaksanaan pembelajaran berjalan baik sehingga mendapat hasil yang maksimal. Bagi guru supaya dapat membimbing pembelajaran sesuai dengan apa yang direncanakan dan lebih kreatif dalam memanfaatkan media yang ada sehingga proses pembelajaran berjalan dengan baik dan menggairahkan bagi peserta didik.

\section{DAFTAR RUJUKAN}

Alwasilah, A.C \& Senny, S.A. (2005). Pokoknya Menulis. Bandung:PT. Kiblat Buku Utama.

Chaer, Abdul dan Agustinas Leonie. 2004. SosiolinguistikPerkenalan Awal. Jakarta : PT. Asdi Mahasatya.

Daryanto.(2014). Pendekatan Pembelajaran Saintifik. Yogyakarta:Penerbit Gava Media

Harymawan. 1993. Dramaturgi. Bandung: PT Remaja Rosdakarya.

Nugroho, Adi. 2016. Pelaksanaan Pembelajaran Menulis Naskah Drama Kelas XI Olah Raga Di SMA Negeri 5 Kota Magelan[Skripsi]. Yogyakarta:Universitas Negeri Yogyakarta. Rusman. 2013. Belajar dan Pembelajaran Berbasis Komputer. Bandung:Alfabeta 
Aswan, Zain. 2010. Strategi Belajar Mengajar. Jakarta:Rineka Cipta. S

Uno, Hamzah B. 2006. Perencanaan Pembelajaran. Gorontalo:PT.Bumi Askara.

Waluyo J, Herman. 2001. Drama, Teori dan Pengajarannya. Yogyakarta: PT. Hanindita Graha Widya Yogyakarta.

Wiyanto Asul. 2007. Terampil Bermain Drama. Jakarta: Grasindo 